\title{
Protective hybrid coating containing silver, copper and zinc cations effective against human immunodeficiency virus and other enveloped viruses
}

\author{
Jan Hodek', Veronika Zajícová2, Irena Lovětinská-Šlamborová2,3, Ivan Stibor ${ }^{2,4}$, Jana Müllerová ${ }^{2,4}$ and Jan Weber ${ }^{1 *}$
}

\begin{abstract}
Background: Healthcare-acquired infections by pathogenic microorganisms including viruses represent significant health concern worldwide. Next to direct transmission from person-to-person also indirect transmission from contaminated surfaces is well documented and important route of infections. Here, we tested antiviral properties of hybrid coating containing silver, copper and zinc cations that was previously shown to be effective against pathogenic bacteria including methicillin-resistant Staphylococcus aureus. Hybrid coatings containing silver, copper and zinc cations were prepared through radical polymerization via sol-gel method and applied on glass slides or into the wells of polymethylmethacrylate plates. A $10 \mu \mathrm{l}$ droplet of several viruses such as human immunodeficiency virus type 1 (HIV-1), influenza, dengue virus, herpes simplex virus, and coxsackievirus was added to coated and uncoated slides or plates, incubated usually from 5 to 240 min and followed by titer determination of recovered virus.

Results: Scanning electron microscopy analysis showed better adhesion of coatings on glass surfaces, which resulted in $99.5-100 \% \mathrm{HIV}-1$ titer reduction $\left(3.1 \pm 0.8 \log _{10} \mathrm{TCID}_{50}, n=3\right)$ already after $20 \mathrm{~min}$ of exposure to coatings, than on coated polymethylmethacrylate plates with $75-100 \%\left(1.7 \pm 1.1 \log _{10} \mathrm{TCID}_{50}, n=3\right)$ and $98-100 \%\left(2.3 \pm 0.5 \log _{10} \mathrm{TCID}_{50}\right.$, $n=3)$ HIV-1 titer reduction after 20 and 120 min of exposure, respectively. Slower virucidal kinetics was observed with other enveloped viruses, where 240 min exposure to coated slides lead to $97 \%$ (dengue), $100 \%$ (herpes simplex) and $77 \%$ (influenza) reduction in virus titers. Interestingly, only marginal reduction in viral titer after 240 min of exposure was noticed for non-enveloped coxsackie B3 virus.
\end{abstract}

Conclusions: Our hybrid coatings showed virucidal activity against HIV and other enveloped viruses thus providing further findings towards development of broad-spectrum antimicrobial coating suitable for surfaces in healthcare settings.

Keywords: Hybrid coating, Virucidal effect, HIV, Enveloped viruses

\section{Background}

Healthcare-associated infections (HAIs) by pathogenic bacteria, viruses and other microorganisms constitute significant cause of morbidity and mortality worldwide. Although exact statistical data are lacking, 1.7 million HAIs were estimated to occur in 2002 in U.S. hospitals alone [1]. More recent survey indicates that everyday approximately 1 of every 25 patients in U.S. acute care

\footnotetext{
*Correspondence: weber@uochb.cas.cz

${ }^{1}$ Institute of Organic Chemistry and Biochemistry AS CR, Flemingovo nam. 2, 16610 Prague 6, Czech Republic

Full list of author information is available at the end of the article
}

hospitals has at least one HAI [2]. Next to direct transmission from person-to-person indirect transmission from contaminated surfaces is also well documented and important route of infections. Self-decontaminating surfaces would represent additional safety measure towards preventing transmission in healthcare settings. In recent years a growing interest is seen in the use of organic-inorganic hybrid materials in medicine, for example antibacterial protective coatings applied on number of devices used in healthcare [3-7], micro and/or nano needles for transdermal drug delivery [8], antibacterial protective coatings on the surface of artificial joints [9], or dental implants [10]. 
Hybrid materials are very conveniently prepared by sol-gel method, which can be briefly described as a special process of glass and ceramics manufacture at room or slightly elevated temperature. This technique became an independent and a very comprehensive discipline, documented by numerous books [11-15] and reviews [16, 17]. With the introduction of organically-modified silicates (ORMOSILs) the sol-gel products started to be an interesting precursor for number of hybrid materials applicable in medicine. Specifically 3-(trimethoxysilyl)propyl methacrylate (TMSPM) either in the pure form or in addition to tetrafunctional silica precursors such as tetraethylorthosilicate (TEOS) or tetramethylorthosilicate (TMOS) allows large variations in optical, mechanical and chemical properties and can be tailored for specific uses $[18,19]$. In addition, the sol-gel process allows the encapsulation of different nanoparticles with known antimicrobial activity e.g. metallic nanoparticles such as $\mathrm{Ag}, \mathrm{Cu}, \mathrm{Zn}, \mathrm{Au}$ etc. $[4,20]$.

From metal nanomaterials with biocidal properties, silver and copper received the most attention. Next to well documented bactericidal activities both silver and copper showed potent virucidal properties [21]. Several studies have confirmed anti-HIV activity of silver nanoparticles [22-24] inhibiting most likely entry step by binding directly with gp120 [25]. Furthermore, silver nanoparticles were shown to inhibit herpes simplex virus type 1 [26] and 2 [27], vaccinia virus [28], respiratory syncytial virus [29], influenza A [30], tacaribe virus [31] and hepatitis B virus [32].

Virucidal activity of copper in the form of copper oxide was evaluated in variety of materials such as fibers, latex, filter matrices and other polymeric materials [33, 34]. Copper oxide-containing filters effectively neutralized HIV-1 in medium and breastmilk and reduced cell-associated HIV in dose-dependent manner [35, 36]. In addition, these filters reduced infectious viral titers of several DNA and RNA viruses, among others yellow fever virus, influenza A virus, measles virus, respiratory syncytial virus, adenovirus type 1 and cytomegalovirus [37]. Recently, it was shown that cuprous compounds deactivate more efficiently bacteriophages and bacteria than cupric compounds [38].

Photoactivation of titanium dioxide by UV generates reactive oxygen molecules on the surface of $\mathrm{TiO}_{2}$ and has been shown to effectively inactivate influenza A virus [39], HIV-1 [40], and murine norovirus [40, 41]. Halogen and interhalogen $\mathrm{TiO}_{2}$ nanoparticles, except for chlorinated adduct, completely inactivated bacteriophages MS-2, $\psi$ X174 and PRD-1, showing that oxidizing potential can be generated without UV photoactivation [42]. Similarly, metal oxide nanoparticles, $\mathrm{CeO}_{2}$ and $\mathrm{Al}_{2} \mathrm{O}_{3}$, and their halogen adducts exhibited excellent virucidal activities against bacteriophages.

In addition to virucidal metal nanoparticles, polymeric coatings with antiviral activities were reported. Coatings based on hydrophobic polycations N,N-dodecyl methylpolyethylenimine on a glass slide lowered influenza infectious titer by at least four fold [43]. Similarly, up to five fold reduction of influenza infectious virus titer was achieved with hyperbranched polymers with quaternary ammonium on glass surfaces, while no significant reduction of infectious poliovirus was detected [44].

Recently, we have reported on new type of hybrid coating containing silver and copper cations with strong antibacterial effect against variety of commonly occurring bacteria in hospital including Staphylococcus aureus and its methicillin-resistant variant [6]. Here, we have tested antiviral properties of this type of hybrid coating.

\section{Methods}

\section{Chemicals}

Tetraethylorthosilicate (TEOS, Sigma-Aldrich, 98 wt.\%), 3-(trimethoxysilyl)propyl methacrylate (TMSPM, SigmaAldrich, 98 wt.\%), methylmethacrylate (MMA, SigmaAldrich, 99 wt.\%), dibenzoylperoxide (BPO, Luperox ${ }^{\circ}$ A75, Sigma-Aldrich, 75 wt.\% and 25 wt.\% of water for stabilisation), titanium isopropoxide (IPTI, Sigma-Aldrich >97 wt.\%), silver nitrate $\left(\mathrm{AgNO}_{3}\right.$, Sigma-Aldrich, 99.8 wt.\%), copper nitrate trihydrate $\left(\mathrm{Cu}\left(\mathrm{NO}_{3}\right)_{2} \cdot 3 \mathrm{H}_{2} \mathrm{O}\right.$, Sigma-Aldrich, 98-103 wt.\%), zinc nitrate hexahydrate $\left(\mathrm{Zn}\left(\mathrm{NO}_{3}\right)_{2} \cdot 6 \mathrm{H}_{2} \mathrm{O}\right.$, Sigma-Aldrich, 98 wt.\%), propan-2-ol (Penta CZ, p.a. 99.98 wt.\%), nitric acid $\left(\mathrm{HNO}_{3}\right.$, Lach:ner CZ, p.a. 65 wt.\%), distilled water, photoinitiator Irgacure 819 (Ciba CZ, 45 wt.\%). Substrates used for preparation of hybrid coatings; glass covering, size $18 \times 18 \mathrm{~mm}$ with thickness $0.13-0.17 \mathrm{~mm}$, (INTRACO MICRO, CZ); poly(methyl methacrylate) - Cell Culture Plates (PMMA), size $75 \times 125 \times 15 \mathrm{~mm}$, (Corning Incorporated NY, Costar, USA).

\section{Sol synthesis}

Silver nitrate $(0.12 \mathrm{~g}, 0.71 \mathrm{mmol})$ was dissolved in $26 \mathrm{ml}$ of propan-2-ol by stirring at room temperature for $60 \mathrm{~min}$. Subsequently, TEOS (1.9 ml, $8.51 \mathrm{mmol})$, TMSPM $(1.0 \mathrm{ml}, 4.21 \mathrm{mmol})$, MMA (0.9 ml, $8.41 \mathrm{mmol})$ and BPO $(0.1 \mathrm{~g}, 0.41 \mathrm{mmol})$ were added via septum into the flask and the reaction mixture was stirred under the atmosphere of nitrogen at room temperature until all of the BPO dissolved. After that, $0.2 \mathrm{ml}$ of a $2 \mathrm{M}$ solution of nitric acid, distilled water $(0.4 \mathrm{ml}, 22 \mathrm{mmol})$, copper nitrate trihydrate $(0.1 \mathrm{~g}, 0.40 \mathrm{mmol})$ and zinc nitrate hexahydrate $(0.11 \mathrm{~g}$, $0.37 \mathrm{mmol}$ ) were dissolved in $26 \mathrm{ml}$ of propan-2-ol in a separate flask and this solution was added to the sol and stirred intensively at room temperature.

Finally, IPTI $(0.6 \mathrm{ml}, 2.22 \mathrm{mmol})$ was added and the reaction mixture was stirred for another $15 \mathrm{~min}$ at room temperature. The resulting sol was heated to reflux in an oil bath while being stirred for $35 \mathrm{~min}$, then cooled down to room temperature and stored in a polyethylene 
bottle in the dark at $20{ }^{\circ} \mathrm{C}$. A sol prepared in this manner was used within three weeks.

\section{Preparation of substrates for application of coatings}

Glass samples were mechanically cleaned with a commercial detergent (Jar), then rinsed with distilled water, sonicated in the same medium in an ultrasound bath for $5 \mathrm{~min}$ and rinsed with distilled water. Then, they were immersed in nitric acid diluted 1:1 with distilled water for three min, repeatedly rinsed with distilled water and finally with propan-2-ol. The cleaned substrates were stored in propan-2-ol. PMMA samples were washed with a commercial detergent (Jar), then rinsed with distilled water several times and immediately immersed in propan-2-ol in an ultrasound bath for $5 \mathrm{~min}$. Finally, they were rinsed with propan-2-ol and stored in it.

\section{Coating procedures \\ Dip-coating}

The glass substrates were dipped into sol, then were withdrawn at a speed of $4 \mathrm{~cm} \cdot \mathrm{min}^{-1}$.

\section{Flow-coating}

The sol diluted with $1 \%$ solution of the photoinitiator Irgacure 819 (BASF, Switzerland) in molar ratio 1:1 $(300 \mu \mathrm{l})$ was dropped into wells in PMMA plates by calibrated pipette $(\mathrm{V}=300 \mu \mathrm{l})$. The solution was left in the wells for $30 \mathrm{~s}$, and subsequently was removed by the same pipette from each well.

\section{Curing}

The coatings on glass were left for $60 \mathrm{~min}$ at room temperature, then were cured for $3 \mathrm{~h}$ at $150{ }^{\circ} \mathrm{C}$. The coatings on PMMA plates were left for $60 \mathrm{~min}$ at room temperature, then were cured for $1 \mathrm{~h}$ at UV-A (315$400 \mathrm{~nm}$, Philips Actinic BL $15 \mathrm{~W}$, made in Holland). The distance of fluorescent lamp from samples was $30 \mathrm{~cm}$.

\section{Measuring properties of coatings FT- IR spectroscopy}

The measurements of reflective IR spectra were performed on an FT-IR spectrometer Nicolet ${ }^{\mathrm{TM}}$ iSTM10 (Thermo Scientific $\left.{ }^{\mathrm{TM}}\right)$ at room temperature $\left(25^{\circ} \mathrm{C}\right)$. The spectrometer was used with the extension method ATR crystal Ge. For liquid samples, the measurements were performed after evaporation of the solvent. The solid samples were measured on a thin layer of aluminum foil.

\section{Surface morphology - scanning electron microscopy}

The quality and morphology of the hybrid coatings was measured through Scanning Electron microscope Carl Zeiss ULTRA Plus with micro-analytic fragment EDS system Silicon Drift Detector $20 \mathrm{~mm}^{2}$ (SDD) - X-you max (OXFORD Instruments). The transparent samples (magnified 1120x and 18280x) were gold-dusted $3 \mathrm{~nm}$ through QR150R (Quorum Technologies) with ion evaporation system model 1060 SEM Mill (Fischione) and observed (through the In-Lens detector) in the form of secondary electrons SE1.

\section{Cells and viruses}

All cells were mycoplasma negative (routinely tested at Generi Biotech, Czech Republic) and cultured in tissueculture treated polystyrene plates in $5 \% \mathrm{CO} 2$ and at $37^{\circ} \mathrm{C}$. TZM-bl cells (Dr. John C. Kappes, Dr. Xiaoyun Wu and Tranzyme Inc.) and HeLa cells (Dr. Richard Axel) were obtained through the NIH AIDS Reagent Program, Division of AIDS, NIAID, NIH. Madin-Darby canine kidney cells (MDCK) and HB-46 cells were obtained from the American Type Culture Collection (ATCC, Manassas, VA), Vero cells from the European Collection of Cell Cultures and HEK293T cells from Stanford University (Stanford, CA). All cells were maintained in DMEM with L-glutamine, $10 \%$ fetal bovine serum (FBS), $100 \mathrm{U}$ of penicillin/ml and $100 \mu \mathrm{g}$ of streptomycin/ ml (all Sigma-Aldrich, St. Louis, MO). Virus HIV-1 $1_{\text {NL4-3 }}$ was prepared by transfection of plasmid pNL4-3, obtained through the NIH AIDS Reagent Program, Division of AIDS, NIAID, NIH from Dr. Malcolm Martin, into HEK293T cells and after $48 \mathrm{~h}$ supernatant was harvested, filtered through $0.45 \mu \mathrm{m}$ steri-flip, aliquoted and stored at $-80{ }^{\circ} \mathrm{C}$. Human coxsackie B3 virus (strain Nancy) and human herpesvirus 1 (strain $\mathrm{HF}$ ) were obtained from ATCC, influenza virus H1N1 A/Mexico/4108/2009 from Diagnostic Hybrids (Athens, $\mathrm{OH}$ ) and dengue virus type 2 from Dr. Jochen Bodem, University of Wurzburg (Wurzburg, Germany).

\section{Experimental setup for determination of virucidal activity Cover glass experiments}

Coated or uncoated (in control experiment) $18 \times 18 \mathrm{~mm}$ cover glasses were placed into 6-well plate and $10 \mu \mathrm{l}$ droplet of $1.66 \times 10^{5} 50 \%$ tissue cell culture infectious doses $\left(\mathrm{TCID}_{50}\right) / \mathrm{ml}$ of HIV-1 or $3.63 \times 10^{5} \mathrm{TCID}_{50} / \mathrm{ml}$ of influenza $\mathrm{A} / \mathrm{H} 1 \mathrm{~N} 1$ virus or $3.98 \times 10^{6} \mathrm{TCID}_{50} / \mathrm{ml}$ of dengue virus type 2 virus or $1.00 \times 10^{6} \mathrm{TCID}_{50} / \mathrm{ml}$ of herpes simplex type 1 virus (HSV-1), or $3.1624 \times 10^{4}$ $\mathrm{TCID}_{50} / \mathrm{ml}$ of coxsackie B3 virus was applied in the center of the glass. The droplet was immediately covered by uncoated cover glass to spread the virus on the whole area. After incubation at specified time usually 5, 10, 20, $30,60,120$, and $240 \mathrm{~min}, 490 \mu \mathrm{l}$ of $1 \mathrm{X}$ phosphate buffered saline (PBS) was added to the coverslips, the top coverslip was lifted and the virus-exposed sides of both coverslips were washed by pipetting 3 times. We collected the whole washing and used for titer determination. Experiments were performed with three cover glasses for each time point. All virus titer determinations 
of recovered virus were performed with 11 twofold dilutions in triplicate according to the type of virus as mentioned below and virus titer reduction was expressed in percentage or plotted as $\mathrm{TCID}_{50}[\mathrm{IU} / \mathrm{ml}]$ versus time.

\section{Experiments with 96-well plates}

Virus droplet $(10 \mu \mathrm{l})$ of $1.66 \times 10^{5} \mathrm{TCID}_{50} / \mathrm{ml}$ of HIV-1 was placed in the center of wells (coated with photopolymerization and uncoated) in 96-well plate and covered with lid. At 2, 5, 10, 20, 30, 60, and $120 \mathrm{~min} 90 \mu \mathrm{l}$ of $1 \mathrm{X}$ PBS was added to the well, mixed three times by pipetting up and down and removed from the well. All experiments in 96-well plates were performed in triplicate. Recovered virus was immediately titrated according the protocols mentioned below and virus titer reduction was expressed in percentage.

\section{Titer determination}

The determination of all virus titers were performed in triplicate from twofold serial virus dilutions and calculated according the method by Reed and Muench [45]. Methods for the discrimination of infected and uninfected wells were virus specific and are described below.

\section{HIV titer determination}

TZM-bl indicator cell line was used to quantitate HIV titers [46]. Twofold serial dilutions of HIV were added in triplicate to 30,000 TZM-bl cells plated $24 \mathrm{~h}$ before in DMEM with L-glutamine, $10 \%$ fetal bovine serum, 100 $\mathrm{U}$ of penicillin $/ \mathrm{ml}$ and $100 \mu \mathrm{g}$ of streptomycin $/ \mathrm{ml}$. After $48 \mathrm{~h}$ incubation at $37{ }^{\circ} \mathrm{C}$ in $5 \% \mathrm{CO}_{2}$, the supernatant was removed, cells washed with $1 \mathrm{X}$ PBS, fixed with $1 \%$ glutaraldehyde and incubated with X-galactosidase staining solution. After $2 \mathrm{~h}$ of incubation infected wells that developed blue loci were counted as positive. Alternatively, after $48 \mathrm{~h}$ of incubation the firefly luciferase luminescent assay was performed and luminescence was measured in Victor X3 plate reader (Perkin Elmer, Waltham, MA). Wells with relative light units above background (mean of luminescence of negative wells plus two standard deviations) were considered positive.

\section{Dengue virus titer determination}

Immunofluorescence staining was used to visualize infected cells [47]. Briefly, twofold serial dilutions of dengue virus type 2 were added in triplicate to 20,000 Vero cells plated day before in DMEM with $2 \%$ fetal bovine serum, $100 \mathrm{U}$ of penicillin/ml and $100 \mu \mathrm{g}$ of streptomycin/ml. After $72 \mathrm{~h}$ of incubation at $37{ }^{\circ} \mathrm{C}$ in $5 \% \mathrm{CO}_{2}$, cells were fixed with $4 \%$ paraformaldehyde and permeabilized with $0.2 \%$ Triton X-100. Then, cells were washed with $1 \mathrm{X}$ PBS and incubated overnight at $4{ }^{\circ} \mathrm{C}$ with dengue virus type 2 serotype-specific mouse monoclonal antibody, which was harvested from HB-46 cells.
Wells were washed three times with $1 \mathrm{X}$ PBS, incubated 90 min with Cy3-labeled donkey anti mouse IgG (Jackson Immunoresearch Europe) and documented using fluorescence microscope Olympus IX-81 with camera (Hamburg, Germany). ImageJ software (NIH) was used for image analysis and evaluation of positive and negative wells.

\section{Influenza virus titer determination}

Immuno-stained plaque assay using low-viscosity overlay medium developed by Matrosovich et al. [48] was adapted for influenza virus determination. Day before 25,000 MDCK cells were plated in DMEM medium with $10 \%$ FBS. Following day cells were washed twice with $1 \mathrm{X}$ PBS, replenished with DMEM medium without FBS and twofold serial dilutions of influenza virus were added to the cells. After $1 \mathrm{~h}$ of incubation the cells and virus mixture was overlaid with 1:1 mixture of $2.4 \%$ Avicel RC/CL (FMC Biopolymer, Philadelphia, PA) and DMEM without FBS, with $7.5 \%$ bovine serum albumine, $0.5 \mu \mathrm{g} / \mathrm{ml}$ TPCK-trypsin (both from Sigma-Aldrich), 100 $\mathrm{U}$ of penicillin $/ \mathrm{ml}$ and $100 \mu \mathrm{g}$ of streptomycin $/ \mathrm{ml}$. After one day of incubation in $37{ }^{\circ} \mathrm{C}$ in $5 \% \mathrm{CO}_{2}$, the avicel solution was removed from the wells, the cells were washed with $1 \mathrm{X}$ PBS, fixed with $4 \%$ paraformaldehyde, permeabilized with $20 \mathrm{mM}$ glycine $/ 0.5 \%$ Triton X-100 for $20 \mathrm{~min}$ and incubated for $1 \mathrm{~h}$ with 1:2500 dilution of monoclonal influenza A antibody against nucleocapsid (Merck Millipore, Darmstadt, Germany) in $10 \%$ normal horse serum and $0.05 \%$ Tween 80 (both SigmaAldrich). Mouse secondary antibody (1:5000 dilution) in $10 \%$ normal horse serum and $0.05 \%$ Tween 80 was applied for $1 \mathrm{~h}$ and followed by $30 \mathrm{~min}$ of incubation in TrueBlue (KPL, Gaithersburg, MA) until blue plaques developed in infected wells.

\section{Herpes simplex and coxsackie virus titer determination}

Twofold serial dilutions of herpes simplex and coxsackie B3 virus were added to 20,000 Vero cells and 30,000 HeLa cells, respectively. Both cell lines were plated day before in DMEM with 10 \% FBS and following day the medium was replaced with serum-reduced DMEM with $2 \%$ FBS. After 1 h of incubation, the cells and virus mixture was overlaid with 1:1 mixture of $2.4 \%$ Avicel RC/CL and DMEM with $2 \%$ FBS. After three days of incubation in $37{ }^{\circ} \mathrm{C}$ in $5 \% \mathrm{CO}_{2}$ the same procedure was followed as with influenza titer determination with following changes in the virus specific antibody dilutions. HSV-1 infected cells were incubated with 1:800 dilution of anti-HSV type I and II monoclonal antibody and coxsackievirus-infected cells were incubated with 1:1000 dilution of anti-coxsackievirus B3 antibody (both Merck Millipore, Darmstadt, Germany). 


\section{Measurement of cytotoxicity of antiviral coatings}

Six uncoated and twelve coated glass covers (half of the covers were prepared by photopolymerization and half were polymerized by heat) were incubated with $500 \mu \mathrm{l}$ of 1X PBS for $15 \mathrm{sec}$ and for $4 \mathrm{~h}$. After incubation, $50 \mu \mathrm{l}$ of liquid were transferred in triplicate on HeLa and Vero cells, incubated for $72 \mathrm{~h}$ and cytotoxic effect was analyzed by XTT colorimetric assay. Briefly, $50 \mu \mathrm{l}$ of 50:1 mixture of XTT labeling reagent $(1 \mathrm{mg} / \mathrm{ml})$ and PMS electron-coupling reagent $(0.383 \mathrm{mg} / \mathrm{ml})$ was added to the wells and incubated for $4 \mathrm{~h}$ in $37{ }^{\circ} \mathrm{C}$ in $5 \% \mathrm{CO} 2$. Formation of orange formazan dye was measured in Victor X3 plate reader and wells with absorbance lower than cutoff that was calculated as mean of absorbance of wells without virus plus two standard deviations were considered infected.

\section{Statistical analysis}

Data were analyzed using a one-way analysis of variance test and followed by the Bonferroni's multiple comparison test. All differences with a $p$-value less than 0.05 were considered statistically significant. Statistical analyses were performed using GraphPad Prism v.6.05 (GraphPad Software, La Jolla, CA).

\section{Results}

\section{FT-IR spectroscopy}

Figure 1 shows the FT-IR spectra of the organicinorganic sol obtained from the combination of TEOS, TMSPM, MMA, and IPTI in the presence of BPO. The characteristic stretching vibration peaks of $-\mathrm{C}=\mathrm{O}$ (type 1 and type 2) occurred at $1660-1740 \mathrm{~cm}^{-1}$ for type 1 , and $1655-1750 \mathrm{~cm}^{-1}$ for type 2 . The infrared absorption of bimodal frequency distribution occurred due to the conjugation effect between $-\mathrm{C}=\mathrm{O}$ and nearby $-\mathrm{C}=\mathrm{C}$ - and hydrogen bonds. The characteristic stretching vibration peak of $-\mathrm{C}=\mathrm{C}$ - occurred at $1633 \mathrm{~cm}^{-1}$ and the characteristic stretching vibration peak of $\mathrm{BPO}$ initiator occured at $1787-1767 \mathrm{~cm}^{-1}$. In Fig. 1 the progress of free radical polymerization of acrylates is visible (see also Table 1 ). The conjugated $-\mathrm{C}=\mathrm{C}-\mathrm{C}=\mathrm{O}$ group is gradually transformed into -C-C-C $=\mathrm{O}$ and this change is acompanied by weakening of $-\mathrm{C}=\mathrm{C}$ - band. At the same time the $-\mathrm{C}=\mathrm{O}$ of $\mathrm{BPO}$ is weakening as well as this compound gradually decomposes. It confirms that TMSPM and MMA molecules were bound together and most likely also grafted on the $\mathrm{SiO}_{2}$ in the process of TEOS and TMSPM co-hydrolysis.

\section{Surface morphology obtained through SEM}

The surfaces of hybrid coatings were analyzed using SEM on two types of substrates; PMMA plates (Fig. 2a, b) and glass (Fig. 3a, b). It confirmed that the hybrid coatings almost precisely copied the surface of the substrates (Fig. 2 and 3).

We observed a number of clearly visible pores in size of few nm on the coated PMMA sample (Fig. 2b), in contrary to that on the coated glass sample, where the number of pores was lower. This can be attributed to the different type of polymerization used. The photopolymerization with photoinitiator Irgacure 819 was used for coating PMMA samples via UV-A (range 315-400 nm). It was dictated by temperature sensitivity of PMMA that is not stable at temperature higher than $60{ }^{\circ} \mathrm{C}$. The glass samples, however, were polymerized by heating for $3 \mathrm{~h}$ at $150{ }^{\circ} \mathrm{C}$. The hybrid coating on the glass substrate (Fig. 3a, b) showed excellent adhesion to the surface. The adhesion of the hybrid coating to PMMA substrate

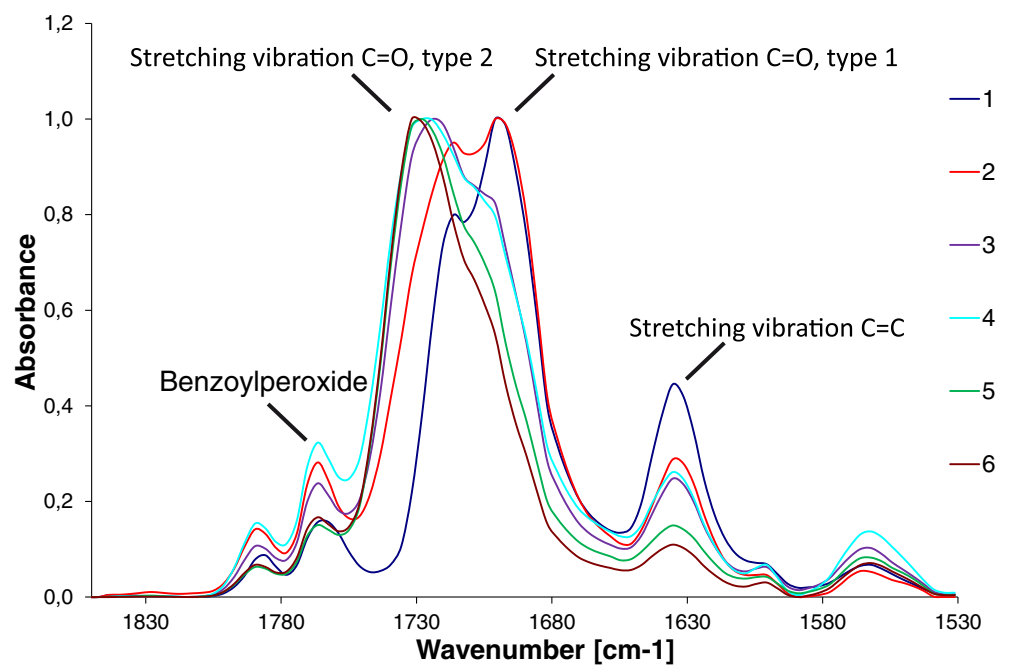

Fig. 1 FT-IR; polymerization of the sol. Sampling in different time intervals (1- 5 min of sol reflux; $2-10$ min of sol reflux; $3-15$ min of sol reflux; $4-20$ min of sol reflux; 5 - 25 min of sol reflux; $6-35$ min of sol reflux) 
Table 1 FT-IR; a polymerization of the sol used for the preparation of hybrid coatings

\begin{tabular}{lll}
\hline Sample & Time & Stretching vibrations of $\mathrm{C}=\mathrm{O}$ and $\mathrm{C}=\mathrm{C}$ groups \\
\hline 1 & 5 min reflux & $1787-1767 \mathrm{~cm}^{-1}$ stretching vibration \\
2 & 10 min reflux & $-\mathrm{C}=\mathrm{O}$ bonds (BPO) \\
3 & 15 min reflux & $1660-1740 \mathrm{~cm}^{-1}$ stretching vibration \\
4 & 20 min reflux & $-\mathrm{C}=\mathrm{O}$ bonds, type 1 (MMA) \\
5 & 25 min reflux & $1655-1750 \mathrm{~cm}^{-1}$ stretching vibration \\
6 & 35 min reflux & $-\mathrm{C}=\mathrm{O} \mathrm{bonds,} \mathrm{type} \mathrm{2} \mathrm{(propionate)}$ \\
& & $1633 \mathrm{~cm}^{-1}$ stretching vibration $-\mathrm{C}=\mathrm{C}$ - bonds \\
\hline
\end{tabular}

was much weaker which might be improved by plasma treatment of PMMA surface prior coating.

\section{Cytotoxicity of hybrid coatings to Vero and HeLa cells}

The cytotoxicity of washings from hybrid coatings with silver, copper and zinc prepared by heat and photopolymerization were evaluated in Vero and HeLa cell lines at two time points (Fig. 4) Immediate cytotoxic effect was assessed after $15 \mathrm{sec}$ exposure to coated glass and resulted in no loss of viability of Vero cells and only small (2-5 \%) loss of viability of HeLa cells. Even exposure for four hours did not release any significant toxic material from coated glass coverslips, which is demonstrated by the viability values above $90 \%$ for both cell lines and both polymerization methods. The lowest viability was observed with hybrid coatings prepared by heat polymerization with $95 \%$ viability for Vero cells and $91 \%$ viability for HeLa cells when compared to the viability of washings from uncoated glass slides after $15 \mathrm{sec}$ exposure.

\section{Anti-HIV-1 activity of hybrid coatings on glass slides}

As a first step in evaluating the virucidal activity of hybrid coatings we coated six glass coverslips by heat polymerization, six by photopolymerization and six were left uncoated. We applied $10 \mu \mathrm{l}$ of HIV-1 on the coverslip and incubated three coverslips for $5 \mathrm{~min}$ and three coverslips for $20 \mathrm{~min}$. The Table 2 displays recovered HIV-1 titer after washing with $0.49 \mathrm{ml}$ of 1X PBS for each coverslip. We found no statistically significant difference in HIV-1 viability between 5 and 20 min exposure of HIV-1 to uncoated glass coverslips with HIV-1 titers of 3981 $\mathrm{TCID}_{50} / \mathrm{ml}$ and $2987 \pm 1721 \mathrm{TCID}_{50} / \mathrm{ml}$, respectively. Moreover, recovered virus titer approximately matched initial input of HIV-1 $\left(3320 \mathrm{TCID}_{50} / \mathrm{ml}\right)$ after similar dilution in $0.49 \mathrm{ml}$ of PBS without exposure to the uncoated glass coverslip. Decrease in HIV-1 titer was already noticeable after 5 min exposure to hybrid coatings. The decrease was smaller in the case of glass coverslips with hybrid coatings prepared by heat polymerization with $79 \% \mathrm{HIV}-1$ titer reduction on average, than in the case of glass coverslips with hybrid coatings prepared by photopolymerization where the reduction was $98 \%$. Similarly, $20 \mathrm{~min}$ exposure of HIV-1 on glass coverslips with hybrid coatings prepared by photopolymerization exhibited better virucidal activity that resulted in $100 \%$ inactivation of HIV-1 on two out of three coverslips than coverslips coated by heat polymerization where $10 \%$ of residual HIV-1 activity remained.

\section{HIV-1 inactivation on coated PMMA surface}

Next we examined the anti-HIV-1 activity of hybrid coating when applied on poly(methyl methacrylate) surface. Figure 5 summarizes results from three separate experiments each performed in triplicate. We can see quick virucidal effect in first 5 min followed by slower additional virucidal effect during the span of $2 \mathrm{~h}$. Interestingly, complete virucidal efficiency was achieved in only one out of three experiments. Nevertheless, at least $98 \%$ reduction of HIV-1 titer was obtained after $2 \mathrm{~h}$ of exposure to coated PMMA wells.

\section{Effect of hybrid coatings against other viruses}

To assess the virucidal potential of hybrid coatings against other enveloped, nonenveloped, RNA and DNA viruses we selected dengue virus, coxsackievirus, influenza virus and herpes simplex virus. Droplet of $10 \mu \mathrm{l}$ of

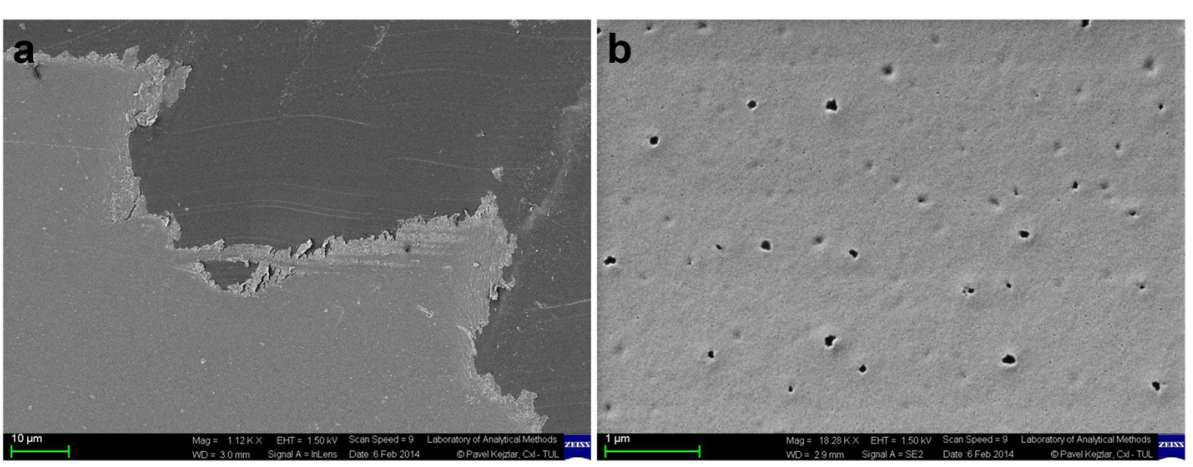

Fig. 2 SEM images of PMMA substrates with hybrid coatings; a the edge of the hybrid coating; $\mathbf{b}$ the hybrid coating contains a large amount of pores in size of a few $\mathrm{nm}$ 

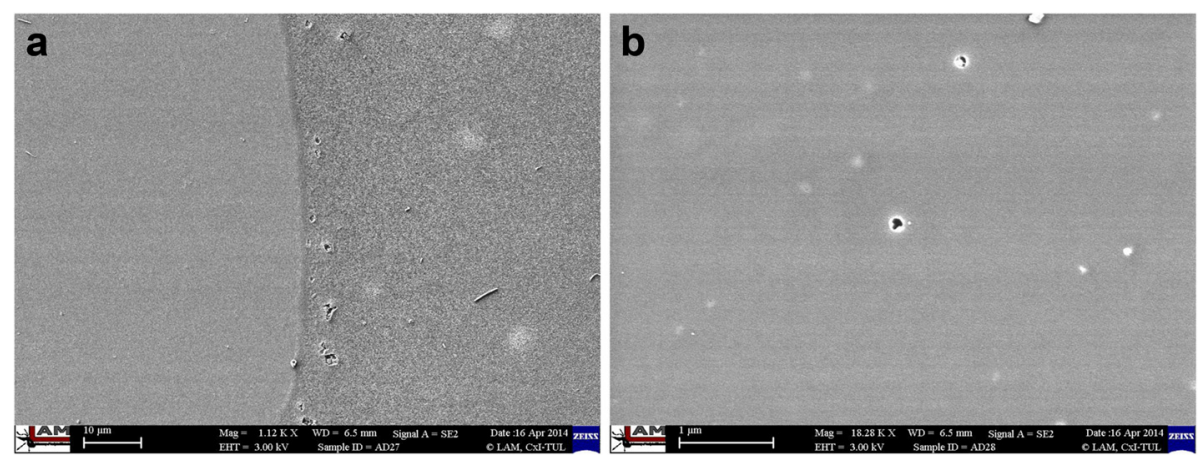

Fig. 3 SEM images of glass substrates with hybrid coatings; a the hybrid coating on the right side of the sample; $\mathbf{b}$ the hybrid coating containing two pores in size of a few $\mathrm{nm}$

each virus was applied on glass coverslips, incubated up to $4 \mathrm{~h}$, titer of recovered virus was determined as specified in Methods section depending on the virus, and plotted in the same graph as titer of recovered virus from untreated glass coverslips (Fig. 6). Very quick initial virucidal effect of hybrid coatings was achieved against dengue virus with $1.1 \log _{10} \mathrm{TCID}_{50}$ reduction after $30 \mathrm{~min}$ exposure, but followed with only additional $1.1 \log _{10} \mathrm{TCID}_{50}$ decline in $4 \mathrm{~h}$. Different course of exposure experiment to hybrid coatings was observed in the case of herpes simplex virus. Similarly $1.0 \log _{10} \mathrm{TCID}_{50}$ decrease of HSV-1 titer was achieved in first $30 \mathrm{~min}$, but complete inactivation was accomplished after $4 \mathrm{~h}$. Only small decrease $\left(0.7 \log _{10} \mathrm{~T}\right.$ $\mathrm{CID}_{50}$ ) of influenza virus titer when compared with untreated control was achieved after $4 \mathrm{~h}$ of exposure to hybrid coating. Even smaller virucidal effect of hybrid coatings than against influenza virus was observed against coxsackie B3 virus, where titers of recovered virus from coated

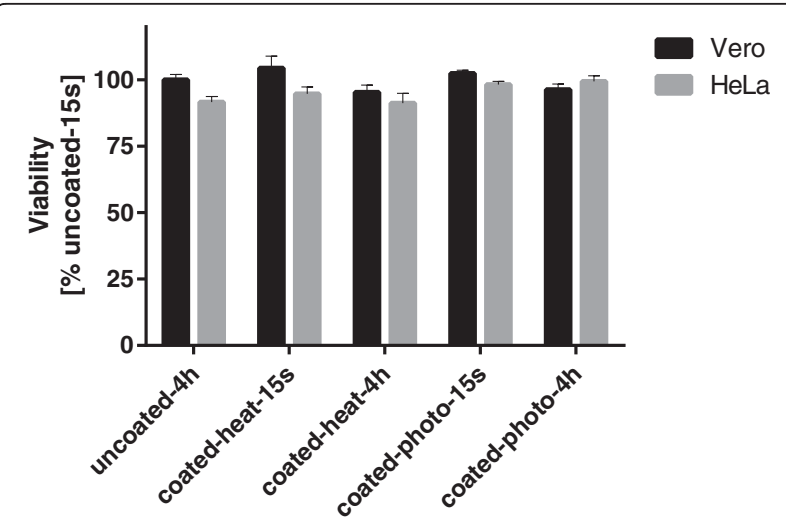

Fig. 4 Effect of hybrid coating washings on Vero and HeLa cells proliferation activity. Vero (black bars) and HeLa (grey bars) cell lines were exposed to washing of coatings on glass coverslip prepared by photo- and heat polymerization after $15 \mathrm{sec}$ and $4 \mathrm{~h}$ of incubation in 1X PBS. Cell viability after $15 \mathrm{sec}$ of incubation with 1 X PBS of uncoated glass coverslip was set as $100 \%$ for each cell line. Error bars indicate standard deviations of results from three glass coverslips coverslips were on average only $0.2 \log _{10} \mathrm{TCID}_{50}$ lower than titers of recovered virus from uncoated coverslips.

\section{Discussion}

Development of broad-spectrum antimicrobial surface coating would represent significant help in the battle against hospital-acquired infections. We recently reported new type of hybrid coating containing silver and copper with strong antibacterial effect against variety of commonly occurring bacteria in hospital including Staphylococcus aureus and its methicillin-resistant variant [6]. To find out the potential antiviral effect, we decided to expose several different viruses to coated glass coverslips and poly(methyl methacrylate) wells in 96-well culture plates.

Our general observation is that the properties of prepared hybrid coatings depend more on the sol synthesis and the subsequent curing method and less on the types of substrate. This fact was further confirmed by the examination of chemical and mechanical resistance on different types of substrate $[6,49]$. The thickness of coatings depends on the method of curing as coatings cured at $150{ }^{\circ} \mathrm{C}$ appear to be thinner than those cured at $90{ }^{\circ} \mathrm{C}$ and, than those cured by photopolymerization. Photopolymerized coatings showed worse mechanical properties than heatpolymerized coatings. These observations need to be further elucidated. According to SEM images, the surface of the glasses was homogeneously covered with the hybrid coatings. The coatings were visible only in the areas where they were mechanically disturbed. A very smooth surface without any visible defects was confirmed also by AFM measurement [49]. We assume that several round-shaped pores were created by gases that evolved at the substrate-coating boundary. Pores are clearly visible in Fig. 2 and 3. Nevertheless, the adhesion of the coatings on glass substrates was very good in both cases of tested polymerizations. There were not identified any places with disrupted adhesion or places containing uncollapsed bubbles with any of the methods used. 
Table 2 Anti-HIV-1 activity of hybrid coating on glass coverslips

\begin{tabular}{|c|c|c|c|c|c|c|}
\hline & \multirow[t]{2}{*}{$\begin{array}{l}\text { Exposure } \\
\text { time [min] }\end{array}$} & \multicolumn{3}{|c|}{$\begin{array}{l}\text { HIV- } 1 \text { titer }\left[T C I D_{50} / \mathrm{ml}\right] \text { after exposure to uncoated } \\
\text { and coated coverslip and after washing with } \\
0.49 \mathrm{ml} \text { of PBS }\end{array}$} & \multirow[t]{2}{*}{$\begin{array}{l}\text { HIV-1 titer } \\
\text { reduction }\end{array}$} & \multirow[t]{2}{*}{$p$-value } \\
\hline & & Coverslip \#1 & Coverslip \#2 & Coverslip \#3 & & \\
\hline \multirow[t]{2}{*}{ Uncoated coverslip } & 5 & 3981 & 3981 & 3981 & - & - \\
\hline & 20 & 3981 & 1000 & 3981 & - & - \\
\hline \multirow[t]{2}{*}{ Coated coverslip by heat polymerization } & 5 & 251 & 1259 & 1000 & $79 \%$ & $<0.001$ \\
\hline & 20 & 316 & 251 & 316 & $90 \%$ & $<0.05$ \\
\hline \multirow[t]{2}{*}{ Coated coverslip by photopolymerization } & 5 & 63 & 63 & 63 & $98 \%$ & $<0.001$ \\
\hline & 20 & 0 & 20 & 0 & $99.8 \%$ & $<0.05$ \\
\hline
\end{tabular}

${ }^{a}$ HIV-1 titer reduction was calculated from average HIV-1 titers from uncoated coverslips set as $100 \%$ minus the quotient between residual average HIV-1 titers from coated coverslips and average titers from uncoated coverslips expressed in percentage

${ }^{b}$ One way analysis of variance test between HIV-1 titers obtained from uncoated coverslips versus coated coverslips at given exposure time

Thorough toxicological analysis of potential adverse effects is essential for successful implementation of hybrid coating in health care settings. In general, $\mathrm{Ag}^{\mathrm{I}+}, \mathrm{Cu}^{\mathrm{I}+}$ and $\mathrm{Zn}^{\mathrm{II}+}$ ions are more toxic than their corresponding nanoparticles $\mathrm{Ag}, \mathrm{CuO}, \mathrm{ZnO}$ [50]. We observed only negligible cytotoxicity effect on Vero and HeLa cells when exposed to washings from coated glass coverslips. Moreover, we did not observe any significant increase in cytotoxicity when washing the coated glass coverslips immediately or after four $4 \mathrm{~h}$ of incubation. This fact shows that the metal ions are immobilized in hybrid coating most likely due to ionic bonding and the leaching of metal ions does not increase significantly during the $4 \mathrm{~h}$ span. It corroborates previous release study from coated cotton swab when the biggest decrease of $\mathrm{Ag}^{\mathrm{I}+}$ and $\mathrm{Cu}^{\mathrm{II}+}$ amount occurred only after first washing cycle and after fifty washing cycles there still remained $40 \%$ of $\mathrm{Ag}^{\mathrm{It}}$ and $20 \%$ of $\mathrm{Cu}^{\mathrm{II+}}$ ions in the coating [6]. Certain degree of metal ions release from hybrid coating is necessary otherwise it would impede the virucidal effect. Here, we have shown that this release is not toxic on two mammalian cell lines but further animal studies to address sensitization and/or irritation are needed.

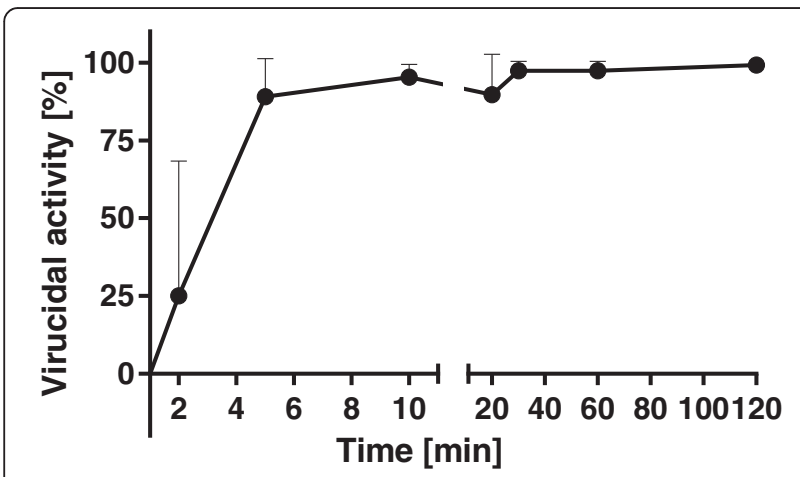

Fig. 5 Time course of HIV-1 inactivation by hybrid coating on PMMA wells. Virucidal activity is expressed as HIV-1 titer reduction in percentage. Error bars indicate standard deviations of three independent experiments performed in three replicate wells for each time point
The antiviral activities of hybrid coating were initially tested against HIV-1 on glass coverslips prepared by the same sol-gel method, which differed only in polymerization process that was either heat- or photoinitiated. Coatings prepared by either curing method showed strong anti-HIV1 activity after $5 \mathrm{~min}$ and further intensified after $20 \mathrm{~min}$. The bigger decrease in residual HIV-1 activity after $20 \mathrm{~min}$ than after $5 \mathrm{~min}$ of exposure of HIV-1 to hybrid coating containing $\mathrm{Ag}^{\mathrm{I}+}, \mathrm{Cu}^{\mathrm{II}+}$ and $\mathrm{Zn}^{\mathrm{II}+}$ ions supports hypothesis that these ions have direct inhibition effect on HIV-1 virions. It is generally accepted that silver and copper ions can exert their biocidal power by directly lysing membranes or by binding to thiol groups of proteins $[34,51,52]$. Zinc was shown to have strong antifungal $[53,54]$ and antibacterial [55-58] effect. In addition, we have plenty evidence of zinc virucidal activity against rhinoviruses [59-61], respiratory syncytial virus [62], vaccinia virus [63], HSV [64] and HIV-1 [65] but exact virus inactivation mechanism is mostly unknown. Kim and coworkers [66] showed that zinc ions can inhibit protein tyrosine phosphatase albeit to much smaller extent that copper ions but by different mechanisms not related to active-site cytosine. Additional proposed mechanisms for HIV-1 inactivation by zinc include inhibition of HIV-1 protease [67] and inhibition of HIV-1 DNA to RNA transcription [65]. Strong evidence that silver nanoparticles inhibit HIV-1 infection by blocking viral entry, particularly gp120-CD4 interaction provided the work of Lara and coworkers [25]. They showed in cell-based fusion assay using Env expressing cells and CD4 expressing cells mixture that silver nanoparticles blocked cell fusion in dose-dependent manner. The CD4 binding domain of gp120 has three disulfide bonds that would represent good target to interact with the virion not only for silver ions but also for copper ions. From reaction with glutathione in an excess of copper in the living cells it is assumed that one $\mathrm{Cu}^{\mathrm{II}+}$ ion can inactivate 3 thiol groups [34].

Next we coated PMMA 96-well plates and confirmed quick and increasing anti-HIV-1 effect during prolonged 
a

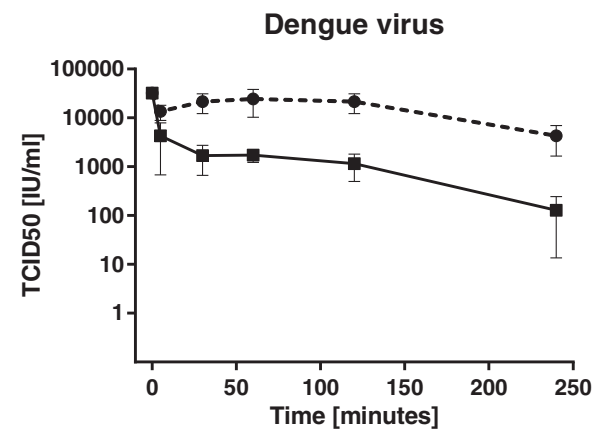

C

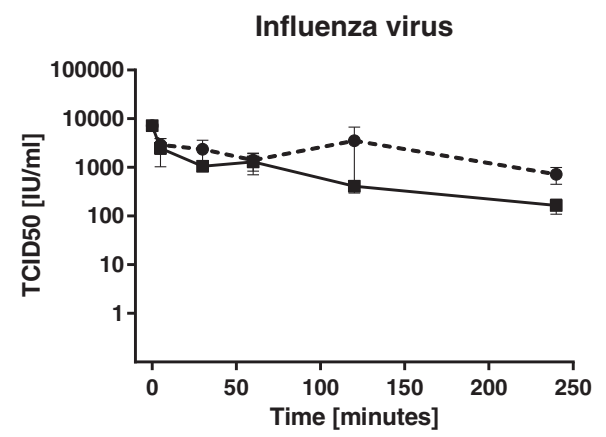

b

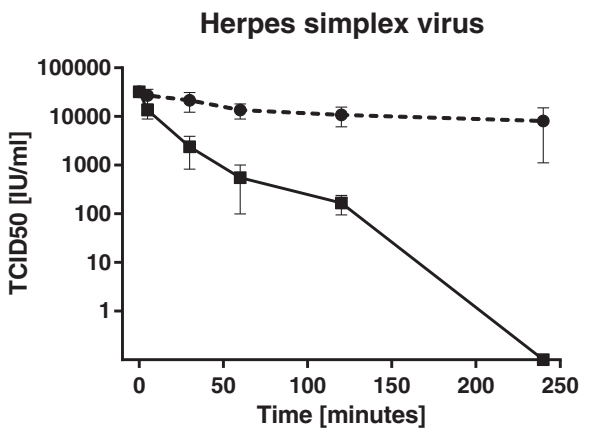

d

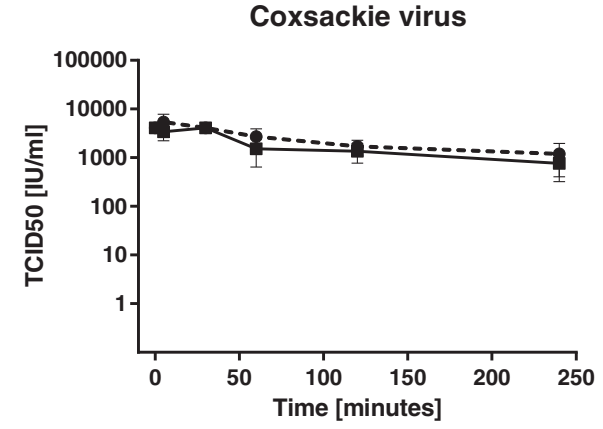

Fig. 6 Time course of virucidal activity of hybrid coatings on glass coverslips against a dengue virus, $\mathbf{b}$ herpes simplex virus, $\mathbf{c}$ influenza virus, and d coxsackie virus expressed as virus titer (black squares with solid line). In each graph is also depicted time course of virus titer after the exposure to uncoated glass coverslips (black circles with dashed line). Error bars indicate standard deviations of three independent experiments

incubation, albeit we achieved on average only $99 \%$ reduction in HIV-1 titer after $2 \mathrm{~h}$ of exposure to hybrid coatings. Better results with glass coverslip experiments can be explained by better adhesion of coatings to glass surfaces as documented by SEM analysis and primarily by the fact that HIV-1 droplet on glass coverslip was covered with another coverslip and thus was more tightly distributed on larger coated surface.

Finally, to determine the hybrid coating ability to inactivate other viruses, we tested four additional viruses representing double-stranded DNA virus, negative and positive sense single-stranded RNA virus and non-enveloped virus. Interestingly, we observed different time course of virus titer reduction for these viruses. Positive single-stranded RNA enveloped dengue virus type 2 had initially quick titer reduction in first $30 \mathrm{~min}$, but it was not followed by complete inactivation even after $4 \mathrm{~h}$ of exposure. There are limited data in the literature about anti-dengue activity of coatings with or without metal ions and nanoparticles. Dengue virus type 2 infection was not suppressed by nanoscale silica platelets hybridized with silver nanoparticles but introduction of anionic sodium dodecyl sulfate efficiently reduced titer almost about three $\log _{10} \mathrm{TCID}_{50}$ [68]. Recently, Murugan et al. reported $80 \%$ reduction of dengue virus type 2 replication by silver nanoparticles at concentration of $50 \mu \mathrm{g} / \mathrm{ml}$ [69]. Binding of dengue virions to host cell receptor is mediated through viral envelope glycoprotein E, which contains 12 strictly conserved cysteine residues forming six disulfide bonds, followed by receptor-mediated endocytosis. Several mammalian cell receptors have been shown to interact with dengue virions such as sulfated glycosaminoglycans, lectins that recognize carbohydrates, glycosphingolipid, proteins with chaperone activity and others [70], but the exact mechanism is still not fully elucidated. Recently, the importance of lipid composition of host cells and virion membrane was highlighted [71]. Quick dengue titer reduction in the first $30 \mathrm{~min}$ of our experiment could signal direct effect on viral membrane and/or disruption of disulfide bonds by metal ions in our hybrid coatings.

In case of double-stranded DNA HSV-1 we have seen different course of virus titer reduction than with dengue virus type 2 . Initial one $\log _{10} \mathrm{TCID}_{50}$ reduction in titer in the first half hour was followed by complete inactivation after $4 \mathrm{~h}$. HSV entry is complex event involving five glycoproteins and three alternative cellular receptors with heparan sulfate being the most important but not essential [72]. Baram-Pinto and coworkers prepared silver nanoparticles 
capped by mercaptoethane sulfonate that mimic polysulfonated heparan and showed that these modified nanopraticles block the attachment of the virus to host cells [26]. Moreover, unmodified silver nanoparticles after one hour preincubation with HSV-2 inhibited subsequent infection of Vero cells with $\mathrm{EC}_{50}=25 \mu \mathrm{g} / \mathrm{mL}$ [27]. Based on our results, that HSV-1 is completely inactivated after extended contact with the coating, we can hypothesize additional mechanism of HSV-1 inactivation besides direct interaction with virion particle. One of the possible mechanisms of action could be disruption of viral double-stranded DNA (dsDNA) by metal ions. It has been shown that silver, zinc and especially copper ions have specific affinity for dsDNA $[32,34,73]$. This mechanism was postulated for inhibition of partially double stranded hepatitis B virus by silver nanoparticles, which were able to reduce extracellular hepatitis $\mathrm{B}$ virus DNA by more than $50 \%$ and thus inhibit the formation of intracellular HBV RNA.

The effect of hybrid coating against influenza A virus lead to only $0.7 \log _{10} \mathrm{TCID}_{50}$ reduction after $4 \mathrm{~h}$ of exposure. Inhibition of influenza A was previously reported with silver nanoparticles, but the strongest inhibitory effect was achieved at rather high concentration of $50 \mu \mathrm{g} / \mathrm{ml}$ of silver nanoparticles [30]. Copper oxidebased filter reduced influenza A virus titer by $1.77 \pm 0.87$ $\log _{10} \mathrm{TCID}_{50}$ during $40 \mathrm{~min}$ filtration [37]. Mechanism for silver or copper ions anti-influenza activity is unknown. Recently, functionalized gold nanoparticles with sialic acid-terminated glycerol dendron were found effective against influenza virus that was mediated by blocking the sialic acid receptor on host cell surface, and thus blocking the fusion step of influenza infection [74].

Hybrid coating exerted only negligible effect on nonenveloped positive single-stranded RNA coxsackie B3 virus. Similarly, previously reported rhinovirus type 2, member of the same Picornaviridae family as coxsackie viruses, exhibited only nonsignificant decrease after passing through copper oxide-based filter [37]. These results would support the explanation that our hybrid coatings with silver, copper and zinc ions act mainly directly on the virion surface of the enveloped viruses.

\section{Conclusions}

In summary, we have characterized virucidal effect of hybrid coatings containing silver, copper and zinc cations against different viruses representing double-stranded DNA virus, negative and positive sense single-stranded RNA virus and non-enveloped virus. Our experiments showed good virucidal effect against enveloped viruses especially HIV and together with previously reported excellent antibacterial effect this hybrid coating has potential to provide antimicrobial protection on surfaces and materials in healthcare settings.

\section{Availability of supporting data}

The data sets supporting the results of this article are included within the article.

\section{Ethics approval and consent to participate \\ Not applicable.}

\section{Consent for publications \\ Not applicable.}

\section{Abbreviations}

AFM: atomic force microscopy; ATCC: American type culture collection; BPO: dibenzoylperoxide; DMEM: dulbecco's modified eagle's medium; FBS: fetal bovine serum; FTIR: fourier transform infrared spectroscopy; HAls: healthcareassociated infections; HIV-1: human immunodeficiency virus type 1; HSV1: herpes simplex virus type 1; IPTI: titanium isopropoxide; MDCK: madin-darby canine kidney; MMA: methylmethacrylate; ORMOSILs: organically-modified silicates; PBS: phosphate buffered saline; PMMA: poly(methyl methacrylate); PMS: phenazine methosulphate; SEM: scanning electron microscope;

TCID50: 50 \% tissue culture infective dose; TEOS: tetraethylorthosilicate; TMOS: tetramethylorthosilicate; TMSPM: 3-(trimethoxysilyl)propyl methacrylate; TPCK: tosyl phenylalanyl chloromethyl ketone; XTT: 2,3-bis-(2-methoxy-4-nitro-5sulfophenyl)-2H-tetrazolium-5-carboxanilide.

\section{Competing interests}

The authors declare that they have no competing interests.

\section{Authors' contributions}

J.W. designed the study, wrote and drafted the manuscript. I.S. designed the study and critically revised the manuscript. V.Z. prepared coatings and first draft of the manuscript. J.H. performed experiments to assess virucidal effects of coatings. J.W. and J.H. contributed to analysis of data from virucidal experiments. I.L-Š. prepared coatings and analyzed coating properties. J.M. performed FTIR experiments. All authors read and approved the final manuscript.

\section{Acknowledgements}

We would like to thank Ing. Pavel Kejzlar, Ph.D. for measurements of surface morphology carried out through the SEM (Faculty of Mechanical Engineering, Technical University of Liberec). All virucidal experiments were performed in Biosafety level 3 laboratory at the IOCB. This research was presented in part at the $54^{\text {th }}$ ICAAC, Washington, DC (5 to 9 September 2014).

\section{Funding}

This study was supported through the project Applications of nanomaterials and advanced technologies (number CZ.1.05/3.1.00/14.0295) with co-funding from the European Regional Development Fund and the state budget of the Czech Republic. J.H. and J.W. were supported by research grant from the Ministry of Education, Youth and Sports of the Czech Republic (LK11207). The funding bodies had no involvement in study design; in the collection, analysis and interpretation of data; in the writing of the report; and in the decision to submit the article for publication.

\section{Author details}

${ }^{1}$ Institute of Organic Chemistry and Biochemistry AS CR, Flemingovo nam. 2, 16610 Prague 6, Czech Republic. ²Department of Chemistry, Faculty of Science, Humanities and Education, Technical University of Liberec, Studentska 1402/2, 46117 Liberec 1, Czech Republic. ${ }^{3}$ Institute of Health Studies, Technical University of Liberec, Studentska 1402/2, 46117 Liberec 1, Czech Republic. ${ }^{4}$ Centre for Nanomaterials, Advanced Technology and Innovation, Bendlova 1407/7, 46117 Liberec 1, Czech Republic.

Received: 25 August 2015 Accepted: 21 March 2016

Published online: 01 April 2016

References

1. Klevens RM, Edwards JR, Richards Jr CL, Horan TC, Gaynes RP, Pollock DA, et al. Estimating health care-associated infections and deaths in U.S. hospitals, 2002. Public Health Rep. 2007;122:160-6. 
2. Magill SS, Edwards JR, Bamberg W, Beldavs ZG, Dumyati G, Kainer MA, et al. Multistate point-prevalence survey of health care-associated infections. N Engl J Med. 2014;370:1198-208.

3. Blaser SA, Scheringer M, Macleod M, Hungerbuhler K. Estimation of cumulative aquatic exposure and risk due to silver: contribution of nano-functionalized plastics and textiles. Sci Total Environ. 2008:390:396-409.

4. Dallas P, Sharma VK, Zboril R. Silver polymeric nanocomposites as advanced antimicrobial agents: classification, synthetic paths, applications, and perspectives. Adv Colloid Interface Sci. 2011;166:119-35.

5. Jaiswal S, McHale P, Duffy B. Preparation and rapid analysis of antibacterial silver, copper and zinc doped sol-gel surfaces. Colloids Surf B Biointerfaces. 2012;94:170-6.

6. Slamborova I, Zajicova V, Karpiskova J, Exnar P, Stibor I. New type of protective hybrid and nanocomposite hybrid coatings containing silver and copper with an excellent antibacterial effect especially against MRSA. Mater Sci Eng C Mater Biol Appl. 2013;33:265-73

7. Zhao L, Wang H, Huo K, Cui L, Zhang W, Ni H, et al. Antibacterial nanostructured titania coating incorporated with silver nanoparticles. Biomaterials. 2011;32:5706-16.

8. Vazquez M, Paull B. Review on recent and advanced applications of monoliths and related porous polymer gels in micro-fluidic devices. Anal Chim Acta. 2010;668:100-13.

9. Simchi A, Tamjid E, Pishbin F, Boccaccini AR. Recent progress in inorganic and composite coatings with bactericidal capability for orthopaedic applications. Nanomedicine. 2011;7:22-39.

10. Schizas C, Karalekas D. Mechanical characteristics of an Ormocomp ((R)) biocompatible hybrid photopolymer. J Mech Behav Biomed Mater. 2011:4:99-106.

11. Kozuka H, Almeida RM, Sakka S. Handbook of sol-gel science and technology. 1st ed. New York: Springer; 2005

12. Menaa B, Menaa F, Sharts O. Bioencapsulation in silica-based nanoporous sol-gel glasses. 1st ed. Hauppauge: Nova Science Publishers Inc; 2010.

13. Pagliaro M. Silica-based materials for advanced chemical applications. 1st ed. London: RSC Publishing; 2009.

14. Ruiz-Hitzky E, Ariga K, Lvov YM. Bioinorganic hybrid nanomaterials, strategies, syntheses characterization and application. 1st ed. Weinheim: Wiley-VCH; 2008

15. Wright JD, Sommerdijk NAJM. Handbook of sol-gel materials: Vol. IV Chemistry and applications, 1st edn. London: Taylor and Francis; 2000.

16. Ciriminna R, Fidalgo A, Pandarus V, Beland F, Iharco LM, Pagliaro M. The Sol-Gel Route to advanced silica-based materials and recent applications. Chem Rev. 2013;113:6592-620.

17. Hench LL, West JK. The sol-gel process. Chem Rev. 1990;90:33-72.

18. Bersani D, Lottici PP, Tosini L, Montenero A. Raman study of the polymerization processes in trimethoxysilylpropyl methacrylate (TMSPM). Journal of Raman Spectroscopy. 1999;30:1043-7.

19. Rubio E, Almaral J, Ramirez-Bon R, Castano V, Rodriguez V. Organic-inorganic hybrid coating (poly(methylmethacrylate)/monodisperse silica). Optical Materials. 2005:27:1266-9.

20. Dastjerdi R, Montazer M. A review on the application of inorganic nanostructured materials in the modification of textiles: focus on anti-microbial properties. Colloids Surf B Biointerfaces. 2010;79:5-18.

21. Munoz-Bonilla A, Cerrada ML, Fernandez-Garcia M. Polymeric materials with antimicrobial activity: From synthesis to applications. RSC polymer chemistry series no. 10. London: RSC Publishing; 2014

22. Elechiguerra JL, Burt JL, Morones JR, Camacho-Bragado A, Gao X, Lara HH, et al. Interaction of silver nanoparticles with HIV-1. J Nanobiotechnology. 2005;3:6.

23. Lara HH, Ixtepan-Turrent L, Garza-Trevino EN, Rodriguez-Padilla C. PVP-coated silver nanoparticles block the transmission of cell-free and cell-associated HIV-1 in human cervical culture. J Nanobiotechnology. 2010;8:15

24. Sun RW, Chen R, Chung NP, Ho CM, Lin CL, Che CM. Silver nanoparticles fabricated in Hepes buffer exhibit cytoprotective activities toward HIV-1 infected cells. Chem Commun (Camb). 2005;28(40):5059-61.

25. Lara HH, Ayala-Nunez NV, Ixtepan-Turrent L, Rodriguez-Padilla C. Mode of antiviral action of silver nanoparticles against HIV-1. J Nanobiotechnology. 2010;8:1.

26. Baram-Pinto D, Shukla S, Perkas N, Gedanken A, Sarid R. Inhibition of herpes simplex virus type 1 infection by silver nanoparticles capped with mercaptoethane sulfonate. Bioconjug Chem. 2009;20:1497-502.

27. Hu RL, Li SR, Kong FJ, Hou RJ, Guan XL, Guo F. Inhibition effect of silver nanoparticles on herpes simplex virus 2. Genet Mol Res. 2014;13:7022-8.
28. Trefry JC, Wooley DP. Silver nanoparticles inhibit vaccinia virus infection by preventing viral entry through a macropinocytosis-dependent mechanism. J Biomed Nanotechnol. 2013;9:1624-35.

29. Sun L, Singh AK, Vig K, Pillai SR, Singh SR. Silver nanoparticles inhibit replication of respiratory syncytial virus. J Biomed Nanotechnol. 2008;4:149-58.

30. Xiang DX, Chen Q, Pang L, Zheng CL. Inhibitory effects of silver nanoparticles on H1N1 influenza A virus in vitro. J Virol Methods. 2011;178:137-42.

31. Speshock JL, Murdock RC, Braydich-Stolle LK, Schrand AM, Hussain SM. Interaction of silver nanoparticles with Tacaribe virus. J Nanobiotechnology. 2010;8:19.

32. Lu L, Sun RW, Chen R, Hui CK, Ho CM, Luk JM, et al. Silver nanoparticles inhibit hepatitis B virus replication. Antivir Ther. 2008;13:253-62.

33. Borkow G, Gabbay J. Putting copper into action: copper-impregnated products with potent biocidal activities. FASEB J. 2004;18:1728-30.

34. Borkow G, Gabbay J. Copper as a biocidal tool. Curr Med Chem. 2005;12:2163-75.

35. Borkow G, Lara HH, Covington CY, Nyamathi A, Gabbay J. Deactivation of human immunodeficiency virus type 1 in medium by copper oxide-containing filters. Antimicrob Agents Chemother. 2008:52:518-25.

36. Borkow G, Covington CY, Gautam B, Anzala O, Oyugi J, Juma M, et al. Prevention of human immunodeficiency virus breastmilk transmission with copper oxide: proof-of-concept study. Breastfeed Med. 2011;6:165-70.

37. Borkow G, Sidwell RW, Smee DF, Barnard DL, Morrey JD, Lara-Villegas HH, et al. Neutralizing viruses in suspensions by copper oxide-based filters. Antimicrob Agents Chemother. 2007:51:2605-7.

38. Sunada K, Minoshima M, Hashimoto K. Highly efficient antiviral and antibacterial activities of solid-state cuprous compounds. J Hazard Mater. 2012:235-236:265-70

39. Nakano R, Ishiguro H, Yao Y, Kajioka J, Fujishima A, Sunada K, et al. Photocatalytic inactivation of influenza virus by titanium dioxide thin film. Photochem Photobiol Sci. 2012;11:1293-8.

40. Yamaguchi K, Sugiyama T, Kato S, Kondo Y, Ageyama N, Kanekiyo M, et al. A novel CD4-conjugated ultraviolet light-activated photocatalyst inactivates HIV-1 and SIV efficiently. J Med Virol. 2008;80:1322-31.

41. Lee J, Zoh K, Ko G. Inactivation and UV disinfection of murine norovirus with $\mathrm{TiO} 2$ under various environmental conditions. Appl Environ Microbiol. 2008;74:2111-7.

42. Haggstrom J, Balyozova D, Klabunde KJ, Marchin G. Virucidal properties of metal oxide nanoparticles and their halogen adducts. Nanoscale. 2010;2:529-34.

43. Haldar J, An D, de CL A, Chen J, Klibanov AM. Polymeric coatings that inactivate both influenza virus and pathogenic bacteria. Proc Natl Acad Sci U S A. 2006;103:17667-71.

44. Tuladhar E, de Koning MC, Fundeanu I, Beumer R, Duizer E. Different virucidal activities of hyperbranched quaternary ammonium coatings on poliovirus and influenza virus. Appl Environ Microbiol. 2012;78:2456-8.

45. Reed $\sqcup$, Muench $H$. A simple method of estimating fifty percent endpoints. Am J Hyg. 1938:27:493-7.

46. Wei X, Decker JM, Liu H, Zhang Z, Arani RB, Kilby JM, et al. Emergence of resistant human immunodeficiency virus type 1 in patients receiving fusion inhibitor (T-20) monotherapy. Antimicrob Agents Chemother. 2002:46:1896-905.

47. Wu H, Bock S, Snitko M, Berger T, Weidner T, Holloway S, et al. Novel dengue virus NS2B/NS3 protease inhibitors. Antimicrob Agents Chemother. 2015;59:1100-9.

48. Matrosovich M, Matrosovich T, Garten W, Klenk HD. New low-viscosity overlay medium for viral plaque assays. Virol J. 2006;3:63.

49. Zajicova $V$, Exnar P, Stanova I. Properties of hybrid coatings based on 3-trimethoxysilylpropyl methacrylate. Ceramics-Silikaty. 2011;55:221-7.

50. Bondarenko O, Juganson K, Ivask A, Kasemets K, Mortimer M, Kahru A. Toxicity of Ag, CuO and ZnO nanoparticles to selected environmentally relevant test organisms and mammalian cells in vitro: a critical review. Arch Toxicol. 2013:87:1181-200.

51. Lara HH, Garza-Trevino EN, Ixtepan-Turrent L, Singh DK. Silver nanoparticles are broad-spectrum bactericidal and virucidal compounds. J Nanobiotechnology. 2011;9:30

52. Rai M, Yadav A, Gade A. Silver nanoparticles as a new generation of antimicrobials. Biotechnol Adv. 2009;27:76-83.

53. Dimkpa CO, McLean JE, Britt DW, Anderson AJ. Antifungal activity of $\mathrm{ZnO}$ nanoparticles and their interactive effect with a biocontrol bacterium on growth antagonism of the plant pathogen Fusarium graminearum. Biometals. 2013;26:913-24. 
54. Kairyte K, Kadys A, Luksiene Z. Antibacterial and antifungal activity of photoactivated ZnO nanoparticles in suspension. J Photochem Photobiol B. 2013;128:78-84.

55. Dwivedi S, Wahab R, Khan F, Mishra YK, Musarrat J, Al-Khedhairy AA Reactive oxygen species mediated bacterial biofilm inhibition via zinc oxide nanoparticles and their statistical determination. PLoS One. 2014;9:e111289.

56. Mantecca P, Moschini E, Bonfanti P, Fascio U, Perelshtein I, Lipovsky A, et al. Toxicity evaluation of a new Zn-Doped CuO nanocomposite with highly effective antibacterial properties. Toxicol Sci. 2015;146(1):16-30.

57. Seil JT, Webster TJ. Reduced Staphylococcus aureus proliferation and biofilm formation on zinc oxide nanoparticle PVC composite surfaces. Acta Biomater. 2011;7:2579-84.

58. Tankhiwale R, Bajpai SK. Preparation, characterization and antibacterial applications of ZnO-nanoparticles coated polyethylene films for food packaging. Colloids Surf B Biointerfaces. 2012;90:16-20.

59. Hulisz D. Efficacy of zinc against common cold viruses: an overview. J Am Pharm Assoc (2003). 2004;44:594-603.

60. Korant BD, Kauer JC, Butterworth BE. Zinc ions inhibit replication of rhinoviruses. Nature. 1974;248:588-90.

61. Prasad AS, Fitzgerald JT, Bao B, Beck FW, Chandrasekar PH. Duration of symptoms and plasma cytokine levels in patients with the common cold treated with zinc acetate. A randomized, double-blind, placebo-controlled trial. Ann Intern Med. 2000;133:245-52.

62. Suara RO, Crowe Jr JE. Effect of zinc salts on respiratory syncytial virus replication. Antimicrob Agents Chemother. 2004;48:783-90.

63. Katz E, Margalith E. Inhibition of vaccinia virus maturation by zinc-chloride. Antimicrob Agents Chemother. 1981;19:213-7.

64. Arens $\mathrm{M}$, Travis $\mathrm{S}$. Zinc salts inactivate clinical isolates of herpes simplex virus in vitro. J Clin Microbiol. 2000;38:1758-62.

65. Haraguchi Y, Sakurai H, Hussain S, Anner BM, Hoshino H. Inhibition of HIV-1 infection by zinc group metal compounds. Antiviral Res. 1999:43:123-33.

66. Kim JH, Cho H, Ryu SE, Choi MU. Effects of metal ions on the activity of protein tyrosine phosphatase VHR: highly potent and reversible oxidative inactivation by Cu2+ ion. Arch Biochem Biophys. 2000;382:72-80.

67. Zhang ZY, Reardon IM, Hui JO, O'Connell KL, Poorman RA, Tomasselli AG, et al. Zinc inhibition of renin and the protease from human immunodeficiency virus type 1. Biochemistry. 1991;30:8717-21.

68. Liang JJ, Wei JC, Lee YL, Hsu SH, Lin JJ, Lin YL. Surfactant-modified nanoclay exhibits an antiviral activity with high potency and broad spectrum. J Virol. 2014;88:4218-28

69. Murugan K, Aruna P, Panneerselvam C, Madhiyazhagan P, Paulpandi M, Subramaniam J, et al. Fighting arboviral diseases: low toxicity on mammalian cells, dengue growth inhibition (in vitro), and mosquitocidal activity of Centroceras clavulatum-synthesized silver nanoparticles. Parasitol Res 2015 Oct 14 [Epub ahead of print].

70. Hidari Kl, Suzuki T. Denque virus receptor. Trop Med Health. 2011;39:37-43.

71. Carro AC, Damonte EB. Requirement of cholesterol in the viral envelope for dengue virus infection. Virus Res. 2013;174:78-87.

72. Reske A, Pollara G, Krummenacher C, Chain BM, Katz DR. Understanding HSV-1 entry glycoproteins. Rev Med Virol. 2007:17:205-15.

73. Heim J, Felder E, Tahir MN, Kaltbeitzel A, Heinrich UR, Brochhausen C, et al. Genotoxic effects of zinc oxide nanoparticles. Nanoscale. 2015;7(19):8931-8.

74. Papp I, Sieben C, Ludwig K, Roskamp M, Bottcher C, Schlecht S, et al. Inhibition of influenza virus infection by multivalent sialic-acid-functionalized gold nanoparticles. Small. 2010:6:2900-6.

\section{Submit your next manuscript to BioMed Central and we will help you at every step:}

- We accept pre-submission inquiries

- Our selector tool helps you to find the most relevant journal

- We provide round the clock customer support

- Convenient online submission

- Thorough peer review

- Inclusion in PubMed and all major indexing services

- Maximum visibility for your research

Submit your manuscript at www.biomedcentral.com/submit
C) Biomed Central 